International Journal of Instruction e-ISSN: 1308-1470 • www.e-iji.net

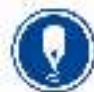

January $2021 \bullet$ Vol.14, No.1

p-ISSN: 1694-609X

pp. $143-160$

Article submission code:

20191116025427

Received: 16/11/2019

Revision: 10/06/2020

Accepted: 29/06/2020

OnlineFirst:11/10/2020

\title{
The Effect of Hands-On and Computer-Based Learning Activities on Conceptual Understanding and Mathematical Reasoning
}

\author{
Nurjanah \\ Department of Mathematics Education, Universitas Pendidikan Indonesia, Indonesia, \\ nurjanah@upi.edu
}

Jarnawi Afgani Dahlan

Department of Mathematics Education, Universitas Pendidikan Indonesia, Indonesia, jarnawi@upi.edu

\section{Yudi Wibisono}

Department of Computer Education, Universitas Pendidikan Indonesia, Indonesia, yudi@upi.edu

The purpose of this study was to compare two treatments, namely the use of hands-on activity media and computer-based media on the conceptual understanding of mathematics and the reasoning ability of junior high school students. In order to obtain complete information about the comparison of the two, researchers also use groups without learning media as a controller. This research approach is quantitative using quasi-experimental methods. The study design was a nonequivalent comparison group design involving seventh-grade students in Bandung Indonesia, totaling 243 people. The research data were obtained using tests of conceptual understanding and mathematical reasoning. The results showed that; the ability to understand mathematical concepts from groups of students who use computer-based media differs significantly from groups of students who use hands-on activity media and control groups. Meanwhile, the ability to understand mathematical concepts of students using hands-on activity media did not differ significantly from the control group. The mathematical reasoning abilities of groups of students who use computer-based media differ significantly from groups of students who use hands-on activity media and control groups. Furthermore, students' mathematical reasoning abilities using hands-on activity media differ significantly from the control group. The use of media, both hands-on activity and computer-based media, contribute to the achievement of student reasoning, especially on the topic of plane geometry being studied. Students can build an understanding of concepts based on their abilities.

Keywords: based on hands-on activity media, computer-based learning, conceptual understanding, mathematical reasoning, learning

Citation: Nurjanah, Jarnawi, \& Wibisono, Y. (2021). The Effect of Hands-On and Computer-Based Learning Activities on Conceptual Understanding and Mathematical Reasoning. International Journal of Instruction, 14(1), 143-160. https://doi.org/10.29333/iji.2021.1419a 


\section{INTRODUCTION}

At this time, with the rapid development of information technology demands the world of education to always adjust the development of technology to businesses in improving the quality of education. It is this change in demands that makes the world of education require innovation and creativity from teachers in the implementation of the learning process by developing learning systems that are technology-based, student-oriented, and facilitate student needs with learning activities that are challenging, active, creative, innovative, effective, and fun.

Innovations that occur in the learning of mathematics make mathematics teachers must 'literate' with the changing times. This has an impact on the teacher's ability to find a match between the learning objectives and the learning strategies used. The development of technology in an increasingly advanced era in the 21 st century has resulted in teachers having to innovate in learning to be done.

Mathematics is an abstract science of space and numbers (Sundayana, 2014). The greatest abstract mathematical object is its difficulty that must be faced by students in learning mathematics. Not only students but, teachers also experience obstacles in teaching mathematics related to its abstract nature. Mathematical concepts can be easily understood if they are concrete.

The nature of mathematical material is not easily understood, and mathematics has a strict and rigid hierarchy (Gagne, 1985), applications of mathematics are less tangible, learning mathematics needs to focus on causing mathematics to be disliked by students. A very basic reason is that mathematics moves in the abstract domain using symbols, formulas, whereas elementary school students or middle school students cannot be fully invited to think abstractly (Ferrari, 2003; Kaminski et al., 2008; Mitchelmore \& White, 2012). On the other hand, students have not reached the formal stage at the age of 15 years (Feldman, 2004). Thus, the level of thinking of middle school students is still at the stage of thinking concretely.

A very basic ability that students must have in learning mathematics is the ability to understand concepts. NCTM (2000) states the ability to understand mathematical concepts into essential abilities that are expected to support students to learn mathematics better and as a basis in understanding and doing the process of learning mathematics. On the other hand, a research report conducted by TIMSS in 2011 and released in 2012 shows the low mathematical ability of the average Indonesian student (Mullis, Martin, Foy, \& Arora, 2012).

The low ability in understanding the concepts and mathematical reasoning of Indonesian students can be seen from the results of the 2018 PISA study released in 2019, where Indonesia ranks 72 out of 78 participating countries (OECD, 2018). Mathematical learning is often about teacher-centered learning, making students understand and comprehend the conceptual understanding, and student punishment does not develop. Students only watch how the teacher demonstrates math problems on the board and students about what the teacher has written during the learning process (Turmudi, 2008, p. 62). Therefore, there is a need for student-centered learning and be able to make 
students active in learning to make students' conceptual understanding and education skills develop.

One form of student-centered learning is computer-based learning. In learning mathematics, in junior high schools, the use of computer-based learning can increase interactions between teachers and students as well as innovative ways to make learning more dynamic, more durable, and more applicable to the world outside the classroom (Almarabeh et al., 2015; Tamur et al., 2018). Teaching and learning material presented through computer media makes students more interested and motivated to learn (Kadaruddin, 2017). Based on these explanations, it is necessary to have media to bridge the student's thinking process from concrete to abstract. Learning media used in the process of learning mathematics can not only be seen, heard, can be read, but can also be manipulated by students, so that learning mathematics becomes easier for anyone. This is in accordance with Confucius's understanding, which states, "what I hear, I forget; what I see, I remember, and what I do, I understand (Hutto, 2009). The nature of learning media that can be manipulated is media based on activity.

The hands-on activity is all activities and direct experience of students with objects where students practice a whole thing with the touch of a hand or manipulating objects by hand (Haury \& Rillero, 1994; Krismanto, 2003). There have been many studies examining the effectiveness of the hands-on activity. In general, research findings show that hands-on activity-based learning is more effective than traditional learning (Anwar, 2019; Celik, 2018; Hussain et al., 2011; Sadi \& Cakiroglu, 2011; Salami, 2014; Shieh \& Chang, 2008). However, Eskrootchi \& Oskrochi (2010) underline the need to investigate the effects of hands-on activity in different ways.

In this connection, NCTM (2000) states the importance of using computer technology media in mathematics learning. Computer-based Learning (CBL) is a teaching method that uses computers to teach students of all levels in a more interactive way (Smyth et al., 2005). The application of CBL in effective learning in increasing student academic achievement (Eskrootchi \& Oskrochi, 2010; Purnamasari \& Herman, 2016; Saad et al., 2015; Winters et al., 2008).

Taher \& Khan (2014) recommends the implementation of computer-based learning (CBL) based hands-on activities in increasing student academic achievement. Highlighting these recommendations, Nurjanah et al. (2019) have developed a media model based on hands-on activity to improve the conceptual understanding ability of junior high school students. In accordance with the advice of Taher \& Khan (2014), this research is intended to go further on the influence of the implementation of hands-on activity-based learning and CBL.

\section{Literature Review}

\section{Hands-On Activity-Based Learning Media}

The hands-on activity is all activities and direct experience of students with objects where students practice a whole thing with the touch of a hand or manipulating objects by hand (Haury \& Rillero, 1994; Krismanto, 2003). Manurung (2010) states that hands- 
on activity is a model designed to involve students in obtaining information and asking questions, conducting activities and finding, collecting data, and analyzing and making their own conclusions. Thus, hands-on activity-based learning is a student's experimental activity to find knowledge directly through one's own experience, constructing understanding and knowledge. In mathematics learning, this activity is synonymous with manipulative activities and practical activities related to hand activities.

Investigation of the effectiveness of hands-on activity-based learning has triggered a flurry of study in the past decade. Research has shown that students can get significant results when hands-on activity-based learning is applied. Hands-on activity-based learning, not only helps students improve their creative skills and problem-solving abilities, but also helps them realize the value of collaboration (Shieh \& Chang, 2008). Hands-on activity-based learning can improve student achievement and attract their learning interest (Anwar, 2019; Celik, 2018; Sadi \& Cakiroglu, 2011).

In another study, it was found that students who were exposed to hands-on activitybased learning had significantly better performance than students in the usual learning groups in the fields of knowledge, understanding, and application (Hussain et al., 2011; Salami, 2014). The research was conducted in different years and times but showed fairly consistent results. This shows the overall trend.

In the field of mathematics teaching, Nurjanah et al. (2019) have developed a media model based on hands-on activity to improve the conceptual understanding ability of junior high school students. They concluded that media based on hands-on activity could build students' understanding of the concept of plane geometry, affect the power of visualization of children, and students longer remember the material being taught. However, Eskrootchi \& Oskrochi (2010) underline the need to investigate the effects of hands-on activity in different ways. Highlighting this, Taher \& Khan (2014) suggested the implementation of hands-on activity-based learning added with the use of computers..

\section{Media Computer-Based Learning Model}

Based on the integration of innovations in technology, programming, and instructional design, the emergence of computer-based learning environments resulted in one of the most critical developments in the history of Education (Campbell, 2003). The use of computer technology is important in learning mathematics (NCTM, 2000). Computerbased Learning (CBL) is a teaching method that uses computers to teach students of all levels in a more interactive way (Smyth et al., 2005). CBL can convey instructions by letting students interact with lessons programmed into the system (Heinich, Molenda\& Russel, 1985).

Educational technology can be applied effectively to improve teaching and learning in mathematics education (Campbell, 2003). In the last decade, this assumption continues to be tested. The researchers found that the application of CBL in learning was effective in increasing student academic achievement (e.g., Eskrootchi \& Oskrochi, 2010; Purnamasari et al., 2016; Saad et al., 2015; Winters et al., 2008). 
Although there are rational reasons, and empirical evidence to support this assumption, the responsibility of educational research is to help uncover more specific conditions and constraints where this assumption actually applies (Mann, Shakeshaft, Becker, \& Kottkamp, 1999; Schacter \& Fagnano, 1999). There are several obstacles in implementing CBL; for example, the time required is too much (Tamur et al., 2018). For this reason, the preparation of computer-based learning must be carried out effectively in accordance with needs. Indrojarwo (2009) explains that the most effective computerbased multimedia presentation is concise narrated animation (CNA). Table 1 below explains CNA.

Table 1

The Concise Narrated Animation (CNA)

\begin{tabular}{ll}
\hline Features & Description \\
\hline Multimedia & Includes amination and interrelated narration. \\
\hline Integrated & Animations and related narratives are presented simultaneously. \\
\hline Solid & Words, pictures, additional sounds that need not be nullified. \\
\hline Salacious & $\begin{array}{l}\text { The words are presented as utterances (so channeled into auditory channels), } \\
\text { not as text or as narrative as well as text. }\end{array}$ \\
\hline Structured & Includes an animation segment for step by step \\
\hline
\end{tabular}

\section{The Conceptual of Understanding}

In the process of learning mathematics, conceptual understanding (understanding concepts) is a very important part. Understanding the concept is an important basis for thinking in solving mathematical problems and problems in everyday life. The ability to understand mathematical concepts, strongly supports other mathematical abilities, namely mathematical communication, mathematical reasoning, mathematical connections, mathematical representation, and problem-solving. Based on the results of research in mathematics learning, Kilpatrick and Findell (2001: 116) conclude that conceptual understanding is the ability to understand concepts, operations, and relationships in mathematics.

NCTM (2000) it is mentioned that understanding concepts is a very important aspect of the principles of mathematics learning. Students in learning mathematics must be accompanied by understanding, and this is a vision of learning mathematics. Conceptual understanding, helping children in learning mathematics (National Research Council, 2001).The ability to understand mathematics helps students to avoid errors of magnitude in particular (Al-Mutawah et al., 2019). Thus, in every learning of mathematics, there must be an understanding of mathematics.

Polya (1957) suggests four levels of understanding of law or concept, namely mechanical understanding, inductive understanding, rational understanding, and intuitive understanding (Polya, 1957). Someone can be said to have a mechanical understanding of a concept if he can remember and apply the concept correctly. Then someone is said to have an inductive understanding of a concept if he has tried the concept applies in a simple case and believes that the concept applies in a similar case. Someone said to have had a rational understanding of a concept if he can prove it. Furthermore, someone is 
said to have an intuitive understanding of a concept, if he has been convinced of the truth of the concept without hesitation. However, understanding the concept, according to some experts have similarities in classifying it, namely instrumental understanding and relational understanding. Instrumental understanding is defined as an understanding of separate concepts and only memorizing the formula and applying it in calculations without knowing the reasons and explanations. On the other hand, in a relational understanding, there is a complex and interrelated schema or structure of knowledge that can be used for solving broader and more complex problems (Anderson \& Krathwohl, 2001; Skemp, 1976; Reys, 1998).

Indicators of understanding mathematical concepts in this study are (1) grouping objects based on certain properties; (2) applying concepts in an algorithmic way, (3) finding patterns from a set of examples, (4) presenting concepts in various forms of mathematical representation, and (5) using concepts and procedures in solving problems related to everyday life.

\section{Mathematical Reasoning}

According to the Big Indonesian Dictionary reasoning is (1) how (about) using reason; logical thinking or way of thinking; range of thought; (2) things develop or control things with reason and not with feelings or experience; (3) mental processes in developing thoughts from several facts or principles (Depdikbud, 2008). While the term as a translation of reasoning is defined as the process of reaching logical conclusions based on relevant facts and sources (Shurter \& Pierce,1996). The reasoning is the process of drawing conclusions that connect known facts or evidence with conclusions (Keraf, 1994). According to Copi et al. (2015), "reasoning is a special type of thinking where inference occurs, where conclusions are drawn from the premise," which means reasoning is a special thought process where conclusions can be drawn, conclusions are based on-premise -permission. So the reasoning is the process of thinking in drawing conclusions based on facts or premises that are considered true.

According to Baroody (1993), there are three main types of reasoning, namely intuitive reasoning, inductive reasoning, and deductive reasoning. Donaldson (1978) divides reasoning into three, namely: (1) Intuitive Reasoning, reasoning that requires a knowledge ready or guessing. Intuitive reasoning is based on a conclusion on whether it is true; (2) Inductive Reasoning, reasoning which includes understanding or regularity. Inductive reasoning starts with testing specific examples and contributing to illustrate a general conclusion. In other words, inductive reasoning requires the observation of specific and sharp examples of patterns or rules; (3) Deductive Reasoning, simple reasoning in describing the conclusions that need to be followed from what we know. In other words, providing certain information, we can check it directly. In this study, the measured reasoning ability is inductive reasoning because it is adjusted to the stage of the cognitive development of junior high school students. 


\section{METHOD}

\section{Model and Design}

The study involved 243 seventh grade students from three state junior high schools in Bandung, Indonesia. The number of students involved in each class from three schools consisted of 81 students. Each school is taken in three classes (two trials and one control). Before conducting research, first given a pretest to ensure equality of initial abilities of students.

This research approach is quantitative using quasi-experimental methods. The quasiexperimental research design used in this study is the nonequivalent comparison group design, which is a better condition for all quasi-experimental research designs (Christensen, Jhonson, \& Turner, 2015). In this study, there are two experimental groups, namely groups of students who study with media activities on hand and groups of students who study with computer-based media. While the control group is a group of students who study conventionally. The design is shown in the following diagram:

\section{PretestMeusure Treatment Posttest}

\section{Measure}

$\begin{array}{llll}\text { Experimental group } & \mathrm{O}_{1} & \mathrm{X}_{1} & \mathrm{O}_{2}\end{array}$

\begin{tabular}{cccc} 
& $\mathrm{O}_{1}$ & $\mathrm{X}_{2}$ & $\mathrm{O}_{2}$ \\
\hdashline Control group & $\mathrm{O}_{1}$ & & $\mathrm{O}_{2}$
\end{tabular}

Information :

$\mathrm{O}_{1}=$ Pretest ability of conceptual understanding and student reasoning

$\mathrm{O}_{1}=$ Posttest ability of conceptual understanding and student reasoning

$\mathrm{X} 1$ = Learning using a media model based on hands-on activity

X2 = Learning using a computer-based learning model

\section{Data Collection}

Data collection instruments used in this study were tests of students' conceptual understanding abilities and mathematical reasoning. The set of questions consists of ten multiple-choice questions and four description questions. Here is an example of a mathematical reasoning problem.

"Suppose farmers have a garden whose surface is shaped like a rectangular field. The garden will plant vegetables. To facilitate the watering of his plants, he made a small ditch from the river next to his garden, as shown in Figure 1 below: 


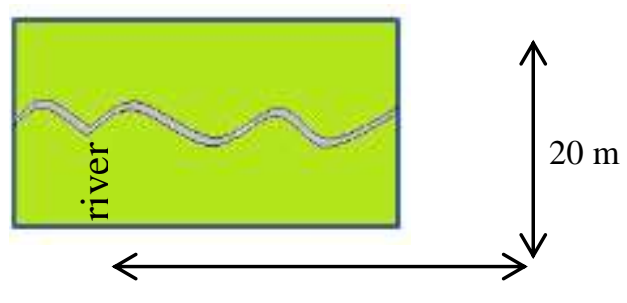

Figure 1

$40 \mathrm{~m}$

Rectangular shaped garden.

If the width of the ditch is $0.5 \mathrm{~m}$, determine the area of the garden where vegetables are only planted!

In an attempt to disarm the threat of internal validity, the instrument developed was tested for its validity and reliability.

\section{Validity Test}

The instrument validity test consists of content validity and face validity. The researcher asked for consideration of four learning experts (lecturers) and four practitioners (teachers). Each item is given number 1 if the experts consider the question valid. Then, given the number 0 , the experts consider the question is invalid. The instrument is said to be valid (in terms of face validity) if it meets the face validity criteria, i.e., if the item has (a) language or editorial clarity, (b) clarity in terms of pictures, and (c) Language used is standard. Furthermore, the instrument is said to be valid (in terms of content validity) if it meets the content validity criteria, i.e., if the item is in accordance with (a) the subject matter provided, (b) indicators of learning achievement, (c) aspects of concept comprehension ability and reasoning measured, and (d) Difficulty level for grade VII junior high school students. All ratings give a score of 1 . The level of agreement among experts is reached by testing the following hypothesis:

- $\mathrm{H}_{0}$ : there is no difference in the results of content validation questions about students' conceptual understanding and mathematical reasoning.

- $\mathrm{H}_{1}$ : there are at least two different results of conceptual content validation and students' mathematical reasoning.

The statistical test used was Q-Cochran with a significance level of 0.05 . The calculation results for content validity from multiple-choice questions and Essays are shown in Table 2 below:

Table 2

Calculation of content validity

\begin{tabular}{lllll}
\hline Questions & $\mathrm{N}$ & Cochran's Q & Df & Asymp. Sig. \\
\hline Multiple Choice & 10 & $9.90^{\mathrm{a}}$ & 7 & 0.190 \\
\hline Essay & 4 & $5.526^{\mathrm{a}}$ & 7 & 0.596 \\
\hline
\end{tabular}


When Table 2 is examined, it appears that the significance value of multiple-choice questions and essays is 0.190 and 0.596 . Both are greater than 0.05 , so the null hypothesis is accepted. Thus, MCQs and essays that measure the ability of students' conceptual understanding and mathematical reasoning meet content validity.

The results of the calculation of face validity are given in the following Table 3:

Table 3

Calculation of face validity

\begin{tabular}{lllll}
\hline Questions & N & Cochran's Q & Df & Asymp. Sig. \\
\hline Multiple Choice & 10 & $6.576^{\mathrm{a}}$ & 7 & 0.474 \\
\hline Essay & 4 & $10.33^{\mathrm{a}}$ & 7 & 0.170 \\
\hline
\end{tabular}

Based on Table 3, it can be seen that the significance value of multiple-choice questions and essays is 0.474 and 0.170 . Both are greater than 0.05 , so the null hypothesis is accepted. So, multiple-choice questions and essays that measure students' conceptual understanding and mathematical reasoning skills meet face validity.

\section{Reliability Test}

The analysis used to calculate the conceptual understanding of multiple-choice reliability is obtained $t$ arithmetic $=4.485$. If $a=0.05$ is taken and with $\mathrm{df}=103$, we get $\mathrm{t}(103 ; 0.05)=1.66$. Because the value of $\mathrm{t}$ arithmetic $=4.485$ is greater than 1.66 , it is concluded that the conceptual understanding of multiple-choice questions is developed reliably. The reliability of the description test uses the Cronbach alpha rule. The calculation results obtained by the correlation value of 0.721 . Thus using $\mathrm{a}=0.05$ and deck $=103, \mathrm{t}(103 ; 0.05)=1.66$. Because the value of $\mathrm{t}$ arithmetic $=4.485$ is greater than 1.66 , it was concluded that the developed understanding test was reliable.

\section{Data Analysis}

After learning is done, a posttest is held for the ability of mathematical understanding and mathematical reasoning in all classes. Posttest for mathematical understanding ability contains ten multiple-choice questions and four essay questions. Likewise, for the posttest, mathematical reasoning ability contains ten multiple-choice questions and four essay questions. After that, the data were analyzed using means, standard deviations, Scheffe tests, and ANOVA with a 5\% significance level.

\section{FUNDINGS}

Descriptive statistical results to illustrate the overall mathematical conceptual understanding ability of students are given in the following Table 4: 
Table 4

Descriptive statistics student mathematical conceptual ability score

\begin{tabular}{lllll}
\hline Descriptives & & & & \\
\hline \multirow{6}{*}{ Hands-On Activities Group } & Statistic & Std. Error \\
\hline & & Mean & 5.76 .54 & .21320 \\
& Computer- & Std. Deviation & 1.91880 & \\
& based & Minimum & 2.00 & \\
& learning & Maximum & 9.00 & .267 \\
& & Skewness & -.386 & .529 \\
\cline { 3 - 5 } Understanding & Kurtosis & -.645 & .18822 \\
& & Mean & 4.2593 & \\
& Hands-on & Std. Deviation & 1.69394 & \\
& activities & Minimum & .00 & \\
& & Maximum & 8.00 & .267 \\
& & Skewness & -.229 & .529 \\
\cline { 3 - 5 } & & Kurtosis & .092 & .15313 \\
& & Mean & 3.9753 & \\
& & Std. Deviation & 1.37818 & \\
& Control & Minimum & 7.00 & \\
& & Maximum & .00 & \\
& & Skewness & .133 & .267 \\
& & Kurtosis & & \\
\hline
\end{tabular}

Based on Table 4, the average results of students' mathematical reasoning abilities are almost the same as mathematical, conceptual understanding abilities. Sequentially groups of students with computer-based learning reach the highest average, then followed by groups of students who use hands-on activities and, finally, groups of students with learning without media and hands-on activities. However, there is a difference in the tendency of data distribution among students with ordinary learning. The highest tendency leads to values above the average. While the group of students with computer-based learningand hands-on activities, although the tendency is negative, the data is gathered a lot close to the average.

From the two results above can illustrate that the use of computer-based learning developed in this study has an impact on students' understanding of ability and reasoning on the topic of the plane geometry. Besides, the diversity of data on comprehension and reasoning abilities also provides information that there is a tendency for strong links between abilities students in understanding with their reasoning abilities.

Table 5

The ability of understanding and reasoning

\begin{tabular}{llllllll}
\hline Source & Dependent Variable & $\begin{array}{l}\text { Type III } \\
\text { Squares }\end{array}$ & Sum ofdf & Mean Square & F & Sig. \\
\hline \multirow{2}{*}{ Group } & Understanding & 152.496 & 2 & 76.248 & 27.271 & .000 \\
\cline { 2 - 7 } & Reasoning & 117.422 & 2 & 58.711 & 24.733 & .000 \\
\hline
\end{tabular}


When Table 5 is examined, both the conceptual understanding ability and the reasoning ability of the three groups are at least two different groups. To see which groups are tested between groups on each variable using the Scheffe method. This test was chosen because it is considered the strongest among the ANOVA follow-up tests. The results of the calculations can be seen in the following Table 6 .

Table 6

Intergroup testing results

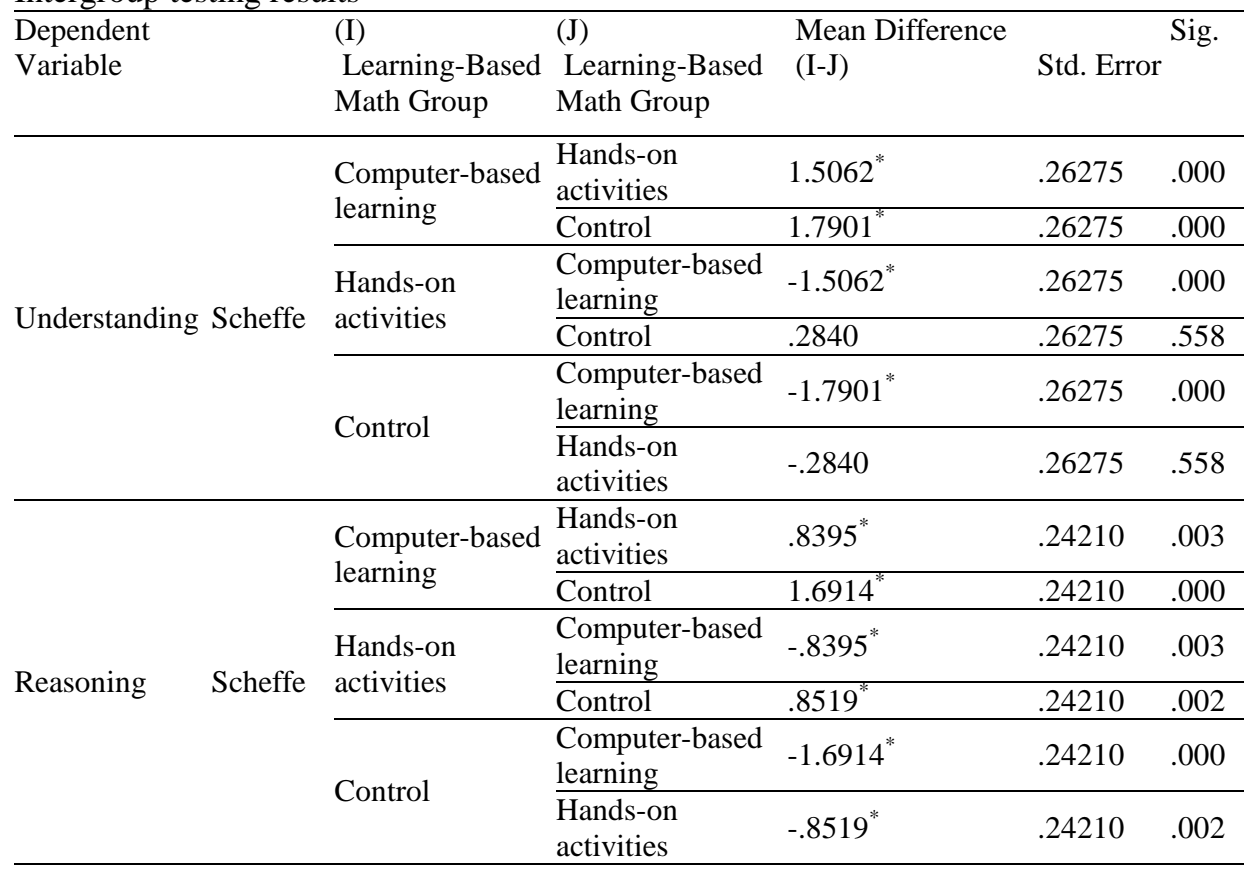

Based on Table 6, mathematical, conceptual understanding abilities, computer-based learning student groups differ significantly from groups of students who use the hand on activity (Hands-on activities) or control groups. Meanwhile, the ability to understand mathematics students who use hands-on activities are not significantly different from the control groups. Slightly different from the results of conceptual understanding ability testing, the results of reasoning ability testing show that the overall grouping is significantly different. The reasoning ability between computer-based learning teaching groups is different from the group of students with the use of hands-on activities and controls, and the reasoning ability in groups with hands-on activities is different from the Control group. Thus it was concluded that the use of media, both computer-based learning and hands-on activities, contributes to the achievement of student reasoning.

\section{DISCUSSION}

This study aims to obtain a holistic picture of the influence of Hands-on Activity and Computer-Based Learning on Conceptual Understanding and Mathematical Reasoning 
in junior high school students. After being treated as much as five third meetings and each school were taken three groups of 2 experimental groups and one control group, it was found that Computer-Based Learning had a significant influence on Conceptual Understanding and Mathematical Reasoning than Hands-On Activity. Not only that, but in this study, there was also a control group which after statistical analysis, found that the group that was given the Computer-Based Learning treatment had a more significant effect.

Researchers try to investigate more deeply the effect of Computer-Based Learning on Conceptual Understanding and Mathematical Reasoning in junior high school students. Computer-Based Learning provides a different experience by providing repetition that will shape students' experiences of Conceptual Understanding and Mathematical Reasoning. This finding is consistent with the relevant findings made previously (Eskrootchi \& Oskrochi, 2010; Kularbphettong et al. 2015; Purnamasari et al., 2016; Smyth et al., 2005). The researchers found that the use of computer-based learning can build knowledge from a combination of experience, interpretation, and structured interaction with peers and teachers. This condition allows students to learn interactively to support the ability of conceptual understanding and mathematical reasoning.

The results of the analysis show that students are more motivated in Computer-Based Learning classes compared to students in hands-on activities classes. Computer-Based Learning not only presents learning material in general, but there are additions such as sound, visuals that are more interesting and can do repetition like video games. As for Practical Activities, it places more emphasis on students' physical activity and understanding of getting up plane geometry, so students are less motivated to do. So, it can be concluded that the motivational aspect plays an important role in maximizing the potential that exists in Computer-Based Learning and Practical Activities. In addition, the motivational aspect, the knowledge aspect, also affects where students will get a lot of knowledge because of variations that add to the students' insights about getting up plane geometry.

In recent years many researchers have focused on research on computer-based learning (e.g., Dahlan et al., 2009; Drigas\& Pappas, 2015; Mashuri, 2017; Munir, 2012; Nurjanah et al., 2017; Nurjanah et al., 2019; Saad et al., 2015). They found that computer-based learning can serve and overcome individual student differences, provide opportunities for experimentation and exploration, students 'speed in mastering the concepts learned is higher, and students' attitudes toward mathematics become more positive. Learning material that is packaged in Computer-Based Learning provides an opportunity for students to better understand mathematical material, especially to get up plane geometry. At the end of the lesson, Computer Based Learning provides questions with a feedback process, so that if students are still working on the problem, they can fix it until the answer is correct. The concept of feedback is very important in the learning process; without feedback, students will not know the consequences of their actions.

The analysis shows that computer-based learning and direct activities are possible for students to improve their conceptual understanding skills. This is in line with the findings of Van den Heuvel-Panhuizen \& Buys (2005) that geometry activities can 
stimulate the ability of children to convey and convey their perceptions, which helps in developing children's thinking skills. This finding is also in line with Taher \& Khan (2014) that students' academic abilities. It is further increased if the use of Hands-onactivity media is combined with computer simulations.

The results showed that students who learned to use Hands-on-activity media were better than students who used conventional learning. This finding is consistent with the results of previous studies (e.g., Anwar, 2019; Salami, 2014; Sadi\&Cakiroglu, 2011; Shieh \& Chang, 2008). The researchers found that the use of Hands-on-activity media can improve students' understanding of concepts. Learning using Hands-on-activity media, students can build their knowledge through the hands-on activities provided. This is in line with Sabandar (2002) opinion that adequate opportunities and equipment need to be provided so that students can observe, explore, try and find geometric principles through informal activities to then continue formal activities and apply what they learn. Learning is carried out on plane geometry materials using practical activities carried out in groups; in this case, the teacher allows students to develop their true abilities. Students who find it difficult to develop their abilities, ask other friends who have understood it first. If this does not work, the teacher provides scaffolding to help students. Meanwhile, through discussions with classmates or asking the teacher and discussed in class together, potential students 'abilities are further developed so that students' understanding of mathematics is even deeper. One of the foundations that can be used to achieve this goal is the Zone of Proximal Development (ZPD) that learning can produce stored mental processes that can only be operated when someone interacts with adults or collaborate with friends (Vygotsky, 1978).

\section{CONCLUSION AND SUGGESTION}

The results showed that, first, mathematical, conceptual understanding abilities, groups of students who use computer-based learning differ significantly from groups of students who use hands-on activities, or control groups. Meanwhile, students' mathematical, conceptual understanding abilities using hands-on activities were not significantly different from the control group. Second, mathematical reasoning abilities, groups of students who use computer-based learning differ significantly from groups of students who use hands-on activities or control groups, and reasoning abilities in groups that use hands-on activities differ significantly from control groups. Third, the use of media, both computer-based learning and hands-on activities, contribute to the achievement of student reasoning, especially on the topic of plane geometry.

Although this study showed significant results in the experimental group, the dependent variable measured was only the ability to understand concepts and mathematical reasoning. The researchers can further expand this research with different independent variables.

\section{Acknowledgments.}

The author thanks the Directorate General of Higher Education, Ministry of Research, Technology and Higher Education, Republic Indonesia, for the financial assistance of $\$ .333 .689$ needed in research. We would also like to thank several junior high schools 
who have expressed their willingness to become research sites in the Bandung City area in Indonesia.

\section{REFERENCE}

Almarabeh, H., Amer, E. F., \& Sulieman, A. (2015). The effectiveness of multimedia learning tools in education. International Journal of Advanced Research in Computer Science and Software Engineering, 5(12), 761-764.

Al-Mutawah, M. A., Thomas, R., Eid, A., Mahmoud, E. Y., \& Fateel, M. J. (2019). Conceptual understanding, procedural knowledge and problem-solving skills in mathematics: High school graduates work analysis and standpoints. International Journal of Education and Practice, 7(3), 258-273. https://doi.org/10.18488/journal.61.2019.73.258.273

Anderson, L.W.\& Krathwohl, D.R. (2001). A taxonomy for learning, teaching and assessing. New York: Addison Wesley Longman.

Anwar, F. (2019). Activity-based teaching, student motivation and academic achievement. Journal of Education and Educational Development, 6(1), 154-170.

Baroody, A.J. (1993). Problem solving, reasoning and communicating. helping children think mathematically (K-8). Urbana: University of Illinois

Campbell, S. R. (2003). Dynamic tracking of elementary preservice teachers' experiences with computer-based mathematics learning environments. Mathematics Education Research Journal, 15(1), 70-82. https://doi.org/10.1007/BF03217370

Celik, H. C. (2018). The effects of activity based learning on sixth grade students' achievement and attitudes towards mathematics activities. Eurasia Journal of Mathematics, Science and Technology Education, 14(5), 1963-1977.

Christensen, L. B., Jhonson, R. B., \& Turner, A. L. (2015). Research methods, desaign, and analysis (Global Edi). Alabama: University of South Alabama.

Copi, I. M., Cohen, C., \& McMahon, K. (2015). Introduction to logic (14th edition). In The effects of brief mindfulness intervention on acute pain experience: An examination of individual difference (Vol. 1). https://doi.org/10.1017/CBO9781107415324.004

Dahlan, J.A, Kusumah, Y.S., \&Sutarno, H. (2009). Pengembangan model computer based e-learning untuk meningkatkan kemampuan high-order mathematical thinking siswa SMA. Penelitian Hibah Bersaing Perguruan Tinggi.: DIKTI.

Depdikbud, P. B. (2008). Kamus besar bahasa Indonesia. Pusat Bahasa, 2008.

Donaldson, M. (1978) Children's minds. Fontana. [aKES]

Drigas, A. S., \& Pappas, M. A. (2015). A review of mobile learning applications for mathematics. iJIM, 3(3), 18-23. http://dx.doi.org/10.3991/ijim.v9i3.4420. 
Eskrootchi, R., \& Oskrochi, G. R. (2010). A study of the efficacy of project-based learning integrated with computer- based simulation - STELLA Project-based learning. $13,236-245$.

Feldman, D. H. (2004). Piaget's stages: The unfinished symphony of cognitive development. New Ideas in Psychology, 22(3 SPEC. ISS.), 175-231. https://doi.org/10.1016/j.newideapsych.2004.11.005

Ferrari, P. L. (2003). Abstraction in mathematics. philosophical transactions of the royal society B: Biological Sciences, 358(1435), 1225-1230. https://doi.org/10.1098/rstb.2003.1316

Gagne, R. (1985). The conditions of learning. 4th ed. New York: Holt, Rinehart \& Winston

Haury, D. L., \& Rillero, P. (1994). Perspectives of hands-on science teaching. columbus the eric clamingouse for science, mathematics and environmental education. (Online). Available on www.Nerel.org/sdis/pathwayg.Html.

Heinich, R., Molenda, M.,\& Russel, J. D. (1985).Instructional media andthenew technologies. 2nd ed. New York: Jhon Wiley and Sons.

Van den Heuvel-Panhuizen, M., \& Buys, K. (2005). Young children learn measurement and geometry. In young children learn measurement and geometry. https://doi.org/10.1163/9789087903985

Hussain, S., Anwar, S., \& Majoka, M. I. (2011). Effect of peer group activity-based learning on students' academic achievement in physics at secondary level effect of peer group activity-based learning on students' academic achievement in physics. International Journal of Academic Research 3 (1). 940-944.

Hutto, D. D. (2009). Philosophical clarification, its possibility and point. Philosophia, 37(4), 629-652. https://doi.org/10.1007/s11406-009-9196-2

Indrojarwo, B. T. (Penyunting). (2009). Multimedia learning prinsip-prinsip dan aplikasi. Yogyakarta: Pustaka Pelajar.

Kadaruddin, K. (2017). Use of computer-based learning multimedia at english departement of universitas sembilan belas november Kolaka. International Journal of Education and Literacy Studies, 5(4), 49. https://doi.org/10.7575/aiac.ijels.v.5n.4p.49

Kaminski, J. A., Sloutsky, V. M., \& Heckler, A. F. (2008). The advantage of abstract examples in learning math. Science, 320(5875), 454-455. https://doi.org/10.1126/science.1154659

Keraf, G. (1994). Argumentasi dan narasi. Jakarta: Penerbit PT Gramedia

Kilpatrik, J., Swafford, J., \& Findell, B. (Eds.). (2001). Adding it up: helping children learn mathematics. Washington, DC: National Academy Press. 
Krismanto. (2003). Beberapa teknik, model dan strategi dalam pembelajaran matematika. Yogyakarta: PPG Matematika.

Kularbphettong, K., Putglan, R., Tachpetpaiboon, N., Tongsiri, C., \& Roonrakwit, P. (2015). Developing of learning for discrete mathematics based on android platform. Procedia-Social and Behavioral Sciences, 197, 793-796.

Mann, D., Shakeshaft, C., Becker, J. D., \& Kottkamp, R. (1999). West Virginia Story: Achievement gains from a statewide comprehensive instructional technology program. 1-46. VCU Educational Leadership Faculty Publications. http://scholarscompass.vcu.edu/edlp_pubs/2.

Manurung, S. (2010). Hand on and mind on activity dalam pembelajaran pengantar fisika kuantum bagi calon guru fisika. Makalah disajikan dalam seminar nasional fisika tahun 2010.

Mashuri, S. (2017). The effectiveness of using computer-based multimedia in teaching geometry at junior high school. International Journal of Innovation and Research in Educational Sciences, 4(5), 621-623.

Mullis, I.V.S., Martin, M.O., Foy, P., \& Arora, A. (2012). TIMSS 2011 international result in mathematics. Chestnut Hill, MA: TIMSS \& PIRLS International Study Center, Boston College.

Mitchelmore, M., \& White, P. (2012). Abstraction in mathematics learning. Springer reference, 3, 329-336. https://doi.org/10.1007/springerreference_226248.

Munir. (2012). Multimedia: konsep \& aplikasi dalam pendidikan. Bandung: ALFABETA.

National Council of Teachers of Mathematics. (2000). Executive summary principles and standards for schools mathematics. Reston, VA: NCTM.

National Research Council, (2001). Adding it up: helping children learn mathematics. Washington, DC: The National Academies Press.

Nurjanah, Dahlan, J. A., \& Wibisono, Y. (2017). Design and development computerbased e-learning teaching material for improving mathematical understanding ability and spatial sense of junior high school students. Journal of Physics: Conference Series, 755(1). https://doi.org/10.1088/1742-6596/755/1/011001

Nurjanah, Dahlan, J. A., \& Wibisono, Y. (2019). Development of media model based on hands-on activity to improve conceptual understanding abilities of junior high school students in Bandung district. Journal of Physics: Conference Series, 1280(4). https://doi.org/10.1088/1742-6596/1280/4/042001.

OECD. (2018). PISA 2018 Results. Journal of Chemical Information and Modeling, 53(9), 1689-1699. https://doi.org/10.1017/CBO9781107415324.004. 
Purnamasari, S., \& Herman, T. (2016). The use of interactive multimedia against the improvement of mathematical understanding and communication abilities, and student learning independence. Eduhumaniora: Jurnal Pendidikan Dasar, 8(2), 178-185

Polya, G. (1957). How to solve it. (p. 242). https://math.hawaii.edu/home/pdf/putnam/PolyaHowToSolveIt.pdf.

Reys, R. E. et. al. (1998). Helping children learn mathematics 5th edition. Boston: Allyn and Bacon.

Saad, S., Dandashi, A., Aljaam, J. M., \& Saleh, M. (2015). The multimedia-based learning system improved cognitive skills and motivation of disabled children with a very high rate. Educational Technology and Society, 18(2), 366-379.

Sabandar, J. (2002). Pembelajaran geometri dengan menggunakan Cabri Geometri II. kumpulan makalah pelatihan. Universitas Sanata Dharma Yogyakarta.

Sadi, O., \& Cakiroglu, J. (2011). Effects of hands- on activity enriched instruction on students' achievement and attitudes towards. Journal of Baltic Science Education, 10(January 2011), 87-97.

Salami, I. A. (2014). Hands-on / mind-on activity-based strategy: The effect on preservice teachers subject matter knowledge in a primary. Journal of Emerging Trends in Educational Research and Policy Studies (JETERAPS), 5(7).

Schacter, J., \& Fagnano, C. (1999). Does computer technology improve student learning and achievement? How, when, and under what conditions? Journal of Educational Computing Research, 20(4), 329-343. https://doi.org/10.2190/VQ8V-8VYB-RKFBY5RU.

Shieh, R. S., \& Chang, W. (2014). Fostering student's creative and problem-solving skills through a hands-on activity. Journal of Baltic Science Education, 13(5), 650-661.

Shurter, R. L., \& Pierce, J. R. (1996), Critical thinking. New York: Mc Graw Hill Inc.

Skemp, R. R. (1976) Relational understanding and instrumental understanding mathematics teaching, 77, 20-26.

Smyth, P., Brabazon, D., \& Loughlin, M. (2005). Review of the methods and effectiveness of computer based learning (Cbl). Physics Teaching in Engineering Education PTEE, September 2005.

Sundayana, R. (2014). Statistika penelitian pendidikan. Bandung: Penerbit: Alfabeta.

Taher, M., \& Khan, A. (2014). Impact of Simulation-based and Hands-on teaching methodologies on students' learning in an engineering technology program 121st ASEE. Annual Conference \& Exposition. https://doi.org/10.5339/qproc.2015.elc2014.58.

Tamur, M., Sennen, E., \& Men, F. E. (2018). Konsep dasar matematika berbasis CAS dan DGS [basic mathematical concepts based-on CAS and DGS]. STKIP St. Paulus Ruteng. 
Turmudi. (2008). Landasan filosofis dan teoritis pembelajaran matematika (berparadigma exploratif dan investigatif). Jakarta: Lauser Cita Pustaka.

Vygotsky, L. S. (1978). Mind in society: The development of higher psychological processes. Cambridge, MA: Harvard University Press. 